\title{
JWL: From Persian to World Literature
}

\author{
Omid Azadibougar \\ University of Göttingen \\ omid.azadi@uni-goettingen.de \\ Esmaeil Haddadian-Moghaddam \\ University of Leuven \\ esmaeil.haddadianmoghaddam@kuleuven.be
}

World Literature is a promising but also hotly debated concept: there is rising interest on various fronts, and its promise as a way out of Eurocentrism and national parochialism brings hope to the world's less commonly studied literatures. However, at the same time it has come under fire for being culturally ungrounded and linguistically shallow, reliant only on translation and some kind of vague American multiculturalism. Is World Literature a dead-end concept? Or is it possible to conceive an idea of World Literature that couples its promises with adequate solutions to proposed linguistic and cultural limits? The Journal of World Literature aspires to lead this discussion and explore the possibilities, presenting works that advance new and creative engagements with local, regional, and global contexts, with original languages as well as translations, in order to contribute to a lively debate from contextual perspectives.

Addressing critiques of World Literature, it is fitting to begin with an example from a context where the issue of compatibility between cultures has been a major and unresolved question for a long time. During the last decades of the twentieth century, intense discussions regarding national culture dominated Iranian intellectual life. These discussions sought ways of reconciling Iranian traditions with the demands of the religious state, on the one hand, and addressed problems of compatibility between modern Western cultural technologies and conceived national identity, on the other. Sometimes, however, the discussions declined into pettiness, such as whether or not wearing jeans would tarnish national or Islamic cultural identity - which, in its own turn, evidences the extreme extent of worries about the influence of other cultures.

Our example comes from a classroom experience of one of us (that is, Omid). In an all-boys high school (all schools were, and still are, segregated) a relatively 
creative teacher who led his composition classes differently asked us to write stories, instead of giving us yet another standard writing topic like "how did you spend your holidays." On the due date, I was eager to read my story to the class. But the first person to read his story was a classmate who seemed even more excited than I was. As he was walking to the front of the class, I thought to myself that my story was unique and would be more "cosmopolitan" than his because I had a character named John in the narrative.

The unsuspecting classmate began reading his story: "One fine spring morning, John decided to ..." and right there, in a fraction of a second, his story was cut short by the rushing palm of the teacher's hand which, targeting his face, sent the notebook one way and the student's distorted face another. This intense anger was caused by the use of "John," an unforgivably foreign name, in the story. The teacher had a Master's degree in Persian Language and Literature and had the additional authority of being the editor of a local newspaper. Therefore, in his conceived role as the guardian of collective cultural identity he silenced the student and cut the story short. In its place, he delivered a long sermon on the importance of "our culture," "our literature," and "our identity." While he was talking, I kept crossing out all Johns in my story, replacing them with an appropriate name - hoping I would not be asked to read my story.

Recent memory in Iran is replete with examples of this guardianship: cultural agents waging war against all things foreign (particularly Western), including non-Persian literature. And when it came to Persian literature, only one standard interpretation has been acceptable which has rendered Hafez's mey (wine) as anything but real wine. But the uncanny presence of John, in two stories written under conditions of cultural purification and formulaic readings of Persian literature, could only be explained in the light of the very same cultural policies. Modern Persian prose had actually had a long history by then, and we even read selected samples of that prose in textbooks. Nonetheless, when it came to reading on our own, we rarely chose to read Persian literature. This was partly due to censorship, which had restricted access to readable materials and left us mostly with lifeless, unappealing pieces of writing.

As a result, we turned to translated literature for good reads, mostly detective fiction, adventure narratives, and love stories, which had appeared in Persian from the early twentieth century. Once we were hooked on reading for pleasure or for knowledge, we also had to learn where to hunt for books. Either you had a relative with a modest library, who in turn happened to be the lucky recipient of books from self-exiled relatives, or you knew someone who, in their turn, knew someone at a library who gave you access to the "closed shelves," or you were given the address of a certain stationary shop which would let you explore their shed for out-of-print books at outrageous prices. In a way, we were reading the 
world's literature by chance, in an unsystematic and yet innocent way: from a favorite of the Iranian left, Nous retournerons cueillir les jonquilles (Laffitte 1948), we moved to the fantasy world of Továrna na absolutno (Čapek 1922) and to the fictional Italian village of Fontamara (Silone 1933), whose portrait of the rebellious Berardo became even more appealing after a namesake television series dubbed in Persian was broadcast during the 1980 s.

As such, television - as the most influential medium - also brought us fascinating characters from other cultures through translation: from the survival of "The Swiss Family Robinson," who were stranded on an island off the coast of Adelaide, to the tribulations of a Japanese woman, Oshin (おしん), who worked hard to support her family, to Sherlock Holmes whose intelligence we worshipped, to stories in which the German police - with their iconic dogstackled murders, to Bruce Lee, who was a paragon of justice and fair use of force. In such a milieu nurtured by translation, it was not at all unexpected that a name such as John would become a name we thought of for a character, particularly when we wanted to write readable and "cosmopolitan" stories.

The incident in the class was not an isolated event. In fact, the impatient interruption of the story by the teacher through an act of violence symbolized the state's censorship of literature. Nevertheless, the necessity of classroom violence was quite ironic: the goal of state censorship had been to sterilize the cultural environment in favor of a particular understanding of "national identity" so that classrooms became comfortably homogenous environments. But very simple tales of murder, adventure, and love, tales that in retrospect seem too simple and banal, had made that ideal purity impossible:John was the "cosmopolitan" and average hero who had become integral to our imagination.

The composition class was, therefore, the site of a clash between purifying cultural policies and translation. It was indeed because of the circumstances that the most apolitical stories became highly political and functioned in unpredictable ways. In the absence of cultural facilities that are often presupposed in liberal societies, we experienced the world not through exchange programs or foreign travel, but rather through translation or anything we could receive - in any language - under the watchful eyes of the national postal service. The translations available to us were probably not the most adequate, as they had been subjected to specific adjustments and, one has to admit, did not bring us the best stories, because the selection of texts for translation has always depended on whether or not they would finally get the required permission for publication; nevertheless, they had a serious impact.

In this view, even though theories hailing from liberal contexts have maximalist expectations of literary translation, we had to cling to what was available. In other words, World Literature was not (and, it seems to us, is not) a constant 
program that means the very same thing everywhere; under differing circumstances, the aims and the tools required for achieving the goal(s) of World Literature will be different: sometimes the purpose is comprehensive familiarity with another literature, while at other times the aim is merely survival under dire cultural conditions.

What is more, whether or not a discourse is political largely depends on how and where it is received. Sherlock Holmes tales, for instance, were highly political not because they had any direct relevance to our situation but rather because they revealed imaginary worlds in which life and the organization of human society was radically different from ours. In that world, which seemed legitimately realistic, solving a murder mystery meant following a chain of motivations among rationally functioning units of existence. This was utterly different from an irrational world we experienced on a daily basis (and also, in fact, different from the in-between world we currently live in). In this sense, translated literature made it possible for us to think of the world in other ways: situations that were not ours and in which we did not participate gave us perspective on our own condition. Similarly, Hemingway's $A$ Farewell to Arms provided a space where the distant, romantic adventures of the American Henry during wwi could be both imagined and contrasted with the news of the Iran-Iraq war, which hardly left any room for romance.

As such, a major goal of reading other literatures was not so much to understand other cultures but rather to enhance our own self-reflexivity. This was not as simple as it sounds: besides adjustments mandated by censorship, the epistemological encounter between different literary histories and traditions led to further discourse transformations, which primarily ensued from the desire to reduce the translated material to preexisting concepts. In this sense, translated literature was often re-coded in what the translator(s) considered acceptable $a$ s literature, even if it meant rendering radical changes in the translated material. These factors notwithstanding, in translation life could no longer be simplified into "us" and "them," good and bad, because the experience of reading even a bad translation was totally different from reading the finest Persian prose.

Nativistic cultural policies, however, do not exclusively emerge in moments of crisis in post-revolution or post-war societies. An event that is strangely similar to the classroom incident may clarify this. One of us (Omid, again) knew a young European couple who were both highly educated in a secular system, and neither was particularly religious. One was a teacher of their national language and literature at high school and the other was an editor at a local publishing house. They were expecting a baby boy, and were telling me about the potential names they had in mind for their kid. In a humorous tone, I suggested that if a white baby boy were named Mohammad it would 
be subversive to cultural presuppositions and could change the relationship between names as representations of cultures and images related to them. The immediate response, contrary to my expectation, was not a laugh or a smile but a serious waving of the index finger. "That," said my friend, "is a no-no name!" The classroom violence was miniaturized, but the cautious tone was the same.

Names are strong markers of ethnic and religious denominations that identify the bearers and indicate their differences. But what made both teachers, separated by time and space, so uncomfortable with foreign names? How did John or Mohammad become keywords that motivate and legitimize the protection of "us" against "them"? Both incidents have uncanny similarities: the teachers teach national Language and Literature, in the latter case the editorial role is carried out by a life partner, and what is most significant is the cultural gap that makes the foreign categorically unacceptable. A major difference, however, is the context where the latter incident took place: it was no longer a post-revolution and post-war cultural atmosphere surrounded by nativistic objectives, but the heart of a rich liberal democracy, with access to all cultural products in the market and on the internet. In other words, the guardians of identity act similarly regardless of time or context, and cultural institutions are capable of producing them everywhere. This is a main reason why World Literature remains a project that is global not only in its aspirations but also in its relevance. In fact, the question of cultural difference implied in both our examples displays the importance of national and cultural boundaries in conceiving an idea of World Literature: not a rootless floating notion above the reality of the world's different traditions, but rather one poised between a cosmopolitan ideal and its roots in various linguistic and literary traditions.

When we discussed a journal proposal in the spring of 2013, for a brief moment we thought of a journal of translation and Persian literature. Our intention was to open the history of Persian literature to all languages that had participated in the formation of this literary space: modern European languages, Arabic, Turkish, and Urdu as well as Iranian languages other than Persian such as Kurdish, Azeri, Baluchi, Lori, etc. But the problem was that understanding Persian literature in a historical perspective did not seem possible without seriously considering the development of literary traditions with which it had been in touch, in one form or another. Otherwise, focusing on a single tradition would lead to the reiteration of a tale that is comfortably familiar but doesn't become any more convincing simply because it is repeated. The envisioned journal would have placed us in a comfort zone, which was prone to ethnocentric narcissism. What we really needed was not only to understand the global from our local perspective, but also to develop the capability to reassess our local from a global point of view. Since our intention was to re-visit the 
canon of classical and modern Persian in a universal sense of literary assessment, we had to widen a literary history that is dominated by critical practices that refuse to go beyond the comfort zone.

A good embodiment of such literary practices, at their most ambitious, is the May 2015 special issue of the International Journal of Iranian Studies dedicated to the theme of World Literature under the title: "The Shahnameh as World Literature." The Shahnameh (Book of Kings) is a canonical epic narrative composed in sixty thousand couplets around the turn of the eleventh century by Abolqasem Ferdowsi. Despite the title, this special issue reveals the problems that ensue from critical practice in a single literary tradition (i.e. Persian), a practice that ultimately negates its explicit objective of examining a canonical work as World Literature. First, despite the references made in passing to translations of the Shahnameh into European languages, the papers in the issue address the book from a perspective that avoids World Literature altogether. World Literature is obviously not national literature under a new tag but a different approach to literary studies. In this special issue, however, the study of the Shahnameh happens in exactly the same way that would have happened without the "World Literature" component of the title. If we are to think of World Literature as more than a fashionable name, requiring a method as well as the willingness to approach literature from an angle other than the national, then the presentation of the case necessarily has to be different. In the issue in question, for instance, apart from a comparison with Beowulf and a brief mention of The Canterbury Tales, there is no mention of other epic narratives; translations into non-European languages are utterly neglected; and, most importantly, the potential impact of other literary traditions on the Shahnameh is ignored.

At the same time, engaging the Shahnameh at this historical moment is a quite ironical project. In view of the nationalistic importance of this epic narrative at a time when retrograde nationalism is on the rise in Iran, this literary focus is flawed in its timing. On the other hand, in contemporary Iranian society, literary discourse is under unprecedented pressure not only from cultural policies that interrupt literary production but also from modern technologies and a capitalistic economy that encourages utilitarianism, and so it is more important than ever before to reconsider the role and function of modern literature and translation as a basis for social co-existence, both at the local and global levels. If classical literature is not the only path to literary and cultural recognition in the world, how does World Literature contribute to Persian and how does the world receive Persian literature? Given that modern literature in Iran is inconceivable without taking issues of translation into consideration, revisiting the role of literature necessitates examining the function of translation. 
In this light, then, a journal of translation and Persian literature would have limited us to a small part of the literary community in the world, i.e. the Western orientalist community, and even then only that part of it dealing explicitly with Persian literature. This approach would have narrowed the potential sources of dialogue and comparative work, in spite of the fact that we intended to enter a wider space to encounter diverse literary histories that are similar and can shed light on contemporary literary and cultural issues. For instance, the literary transformations of Japan's Meiji period (18681912) are not unlike those of the Qajar era (1785-1925), even though their results are totally different; the influence of classical Chinese aesthetics on modern Chinese literature is comparable to the impact of classical Persian on modern literature; the experience of literary modernization in Persian is strikingly similar to the Arabic and Turkish cases, even though their effects have been divergent; the state censorship of literature in Spain under Franco or in communist Eastern Europe is like the current situation in Iran; the Iranian experience of colonization is very different from that in Africa and India, but there are many meaningful echoes of those experiences in this cultural history; and the characters of Machado de Assis, Nikolai Gogol and Lu Xun have their peculiar doubles in Sadeq Hedayat's stories, while the writings of Borges, García Márquez and Vargas Llosa are very popular with Persian readers. So how could one neglect these unexpected affinities to focus only on one literary tradition? While Persian is not the only literature in the world and we are not the only people inhabiting the planet, the West is not the only potential audience for this literary tradition, just as it is not the only source of literary production or inspiration.

Regardless of social conditions, therefore, World Literature is a constant necessity - though not a homogenous program - if the aim is to overcome cultural isolation in an increasingly interdependent world. While any literary tradition needs a John or a Mohammad to become aware of the limits of its knowledge, we also need to understand what motivates literary mobility across languages in the world, in order to outline the way World Literature is formed and to explore the forces that participate in its development over time. The very specificity of the above examples shows the necessity for close cultural engagement: world literary studies doesn't consist solely of sophomore-level survey courses, and the best work in world literature is deeply involved in cultural context and work with original languages to understand the variant conditions under which literature functions.

In order to achieve contextualized and multi-layered insights into the world's literary traditions, forthcoming issues of our journal are planned to address World Literature at several levels and from different perspectives: be- 
sides regular open-call issues that welcome contributions from scholars of different research backgrounds to meet the challenges of a wider and deeper discussion of literature's networks, an approach has been envisioned that involves the regular presence of special issues centering on a particular country or region, other issues of a global reach but with a targeted theme, as well as yearly issues that ensue from the summer sessions of the Institute for World Literature. The Journal of World Literature will hence be the laboratory where the study of World Literature beyond conceived limits is explored; if nothing else, our major achievement will be to discover the ten thousand ways it is not possible.

Launching a journal that could address all the literatures of the world seemed like a daunting task, but we had the good fortune to meet people who had the insight to make this project possible. When we first discussed the idea of the journal with Zhang Longxi, Theo D'haen and David Damrosch, none had a shred of a doubt about the necessity or the possibility of creating such a forum. Likewise, other scholars we contacted were wholeheartedly encouraging, and that is how the Journal of World Literature was conceived.

Now that after almost three years of intensive collective work and planning, things have successfully developed to the publication stage, we would like to thank everyone who helped make this project a success. First, we thank our editors-in-chief for patiently listening to the initial ideas, for giving constructive and effective feedback, for improving and strengthening them substantially into a well-rounded idea with a clear vision. We also thank Kathy van Vliet and Irene van Rossum at Brill, who have given our journal an excellent home. We sincerely thank the members of our editorial board for their positive response as well as the authors who accepted our invitation to contribute to this inaugural issue. We are also grateful to Svend Erik Larsen and Hans Bertens for reading the manuscript on our behalf and providing comprehensive feedback.

This journal is established in the hope of creating a forum for the discussion of literature without ethnocentric prejudice or disciplinary boundaries that separate the study of literature from translation and make some literatures epistemologically irrelevant. This is all possible because of the good will and intentions of great human beings who envision a more inclusive future for literary studies. We could not be more exhilarated or honored to be part of this undertaking. 